\title{
CONVENTION AND DESIGN IN DRAYTON'S HEROICALL EPISTLES
}

\author{
BY RICHARD F. HARDIN
}

$\mathrm{M}^{\mathrm{I}}$ ICHAEL DRAYTON'S Englands Heroicall Epistles were an immediate success with Elizabethan readers: the collection was registered in October 1597, was published later that year, reissued in 1598, newly edited the same year, in 1599,1600 , and $1602 .^{1}$ It reappeared at least seven more times before the author's death in 1631; later seventeenthcentury printings were still to come. It has often been noted that these twenty-four long verse epistles are imitations of Ovid's Heroides, the first of this kind in English. ${ }^{2}$ The distinctive character of Drayton's epistles, however, lies more in their Elizabethan than in their Ovidian heritage. The Heroicall Epistles are an extension of the literary vogue of tragic complaints which attracted Shakespeare, Daniel, Lodge, and Drayton himself. They are also Elizabethan historical poems, and differ from Ovid's epistles in that they are informed by a single controlling purpose: to convey to the reader that same spirit of confident patriotism which characterizes most of the historical poetry and drama of the 1590's.

The idea for Drayton's epistles must have come in part from the popular Elizabethan convention of complaint poems, exemplified in Daniel's Complaint of Rosamond (1592) and Shakespeare's Lucrece (1594). These in turn owe their origin to the earlier complaints or "tragedies" of the Mirror for Magistrates; but they are also influenced by Ovid's love-complaints in the Heroides and Metamorphoses. The earliest poems of the Mirror (1559) are quite unlike the complaints of the 1590's: they emphasize political rather than moral teachings; they lack the figured style and literary allusiveness which grace, and often encumber, the later poems; most important, they do not broach the subject of love until Thomas Churchyard's Shore's Wife (1563). Yet even in Churchyard's poem the emphasis is on Jane Shore's "great overthrowe," not her beauty. The same may be said of the next Mirror complaint to deal with illicit love, John Higgins' Elstride (1574). In Thomas Blenerhasset's tragedy of the virtuous abbess ("How Lady Ebbe dyd flea her nose and upper lippe away to save her Virginitie," 1578) the Mirror poet shifts his concern from the political to the moral; however, his work looks back to legends of the virgin-martyrs rather than forward to the

amorous complaints of the next generation. Lady Ebbe's speech to the nuns of her convent, while the Danes are ravaging the Saxon countryside, typifies the impassiveness of tragic complaints before Daniel:

And for because the faces forme doth move With beauties beames and comely countenaunce, The minde of men to lust and lawlesse love, I have devizde, my honour to advaunce, With face deformde to try my hard mischaunce. For these my hands from this my face shall rippe Even with this knife, my Nose and overlippe.

(11. 78-84)

In The Complaint of Rosamond, the old legend of Henry. II's mistress as well as the nowstereotyped techniques of the Mirror are infused with a new vitality. Hallett Smith has rightly attributed the effectiveness of Daniel's poem to his introduction of the Ovidian manner into the complaint tradition: the "use of rhetoric to heighten the dramatic character of the situation," of "pictorial embellishment," and of the Ovidian wooing speech. ${ }^{3}$ To these characteristics might be added the extensive soul-searching carried out in long monologues or soliloquies, in which the "use of rhetoric to heighten the dramatic character of the situation" is most in evidence. Certainly there is little in earlier English literature that could have suggested to Daniel the form of Rosamond-a tragic monologue by a victim of masculine lust. However, in the Heroides and in parts of the Metamorphoses he would find such material in abundance. ${ }^{4} \mathrm{His}$

'See Drayton's bibliography by B. Juel-Jensen in the corrected edition of The Works of Michael Drayton, ed. J. W. Hebel, with introductions, notes, and variant readings by $\mathrm{K}$. Tillotson and B. H. Newdigate (Oxford, 1961), v, 265-306. Quotations from Drayton are from this edition, cited hereafter as Works.

${ }^{2}$ Criticism of the Epistles is found only in literary histories; as of this writing they are the subject of no monograph in English. See K. Tillotson's introduction in Works, v, 99-101. The standard, although incomplete, source study is W. Claassen, Michael Draytons 'England's Heroical Epistles': Eine Quellenstudie (Borna-Leipzig, 1913).

${ }^{3}$ Elizabelhan Poetry (Cambridge, Mass., 1952), p. 107. For an account of the complaint vogue see Smith, pp. 102-106. Also see Smith, "A Woman Killed with Kindness," PMLA, IIII (1938), 138-147, for the influence of the complaint on drama. A survey of the "progeny" of the Mirror is found in Willard Farnham, The Medieval Heritage of Elizabethan Tragedy (Berkeley, 1936), Ch. viii. 797.

E.g., the self-questioning of Byblis or Iphis, Met. Ix.447- 
many imitators over the next few years show that Daniel had caught the fancy of Elizabethans; ${ }^{5}$ merging the traditional into the Ovidian style, he gratified at the same time his readers' tastes for moral sententiousness and verbal elegance.

A substantial connection between the Elizabethan love-complaints and Ovid's epistles is the frequency with which both impart the woman's point of view. Ovid's Hero spoke on behalf of all suffering womankind in telling Leander: "You men, now in the chase, and now husbanding the genial acres of the country, consume long hours in the varied tasks that keep you..... For me who am denied these things, even were I less fiercely aflame, there is nothing left to do but love. What there is left, I do." As if echoing Hero, Daniel's Rosamond cries, "And o what are we, if we be not lov'd?"' And elsewhere, on the influence at court of a female favorite, "What cannot women doe that know theyr powre?" (1. 128). After her fall Rosamond laments the surrender of "The onely good that women hold so deare" (1. 500). Women, she says, are feeble because they must contend not only with "weakness, beauty, gold, and men," but with their own treacherous selves (II. 729735). In Lucrece, while Shakespeare departs in form somewhat from the conventional tragic monologue, feminine psychology again furnished sententiae for the heroine:

For men have marble, women waxen minds, And therefore are they form'd as marble will:

The weak oppress'd, th' impression of strange kinds Is form'd in them by force, by fraud, or skill:

Then call them not the authors of their ill, No more than wax shall be accounted evil Wherein is stamp'd the semblance of a devil.

(11. 1240-46)

Thomas Lodge's Elstred pleads with Queen Guendolen, "My sexe was weake, my sences farre more weaker" (st. 85).

Drayton must have intended the first of Englands Heroicall Epistles, from Rosamond to Henry II, as tacit acknowledgement that he was working as much in the pattern of Elizabethan complaints as from Ovid's example. Drayton's Rosamond resembles Daniel's in several obvious details, perhaps most significantly in the "faire casket" which both heroines are supposed to contemplate, decked with the same pictures of Neptune, Amimone, Jove, and Io. In her epistle Rosamond also extends the parallel between her situation and that of Io (in Metamorphoses, r.568-746)-a similarity which Daniel's heroine had first observed. ${ }^{7}$ Shake- speare's heroine is recalled when Rosamond's serving-woman points out Lucrece's picture, asking her guilt-ridden mistress to explain it:

Why Girle (quoth I) this is that Roman Dame;

Not able then to tell the rest for shame,

My Tongue doth mine owne Guiltinesse betray; (11. 99-101)

In subsequent epistles Drayton follows Ovid, Daniel, and Shakespeare in his emphasis on feminine psychology, as in the Countess of Salisbury's lines to Prince Edward:

To Men is graunted priviledge to tempt, But in that Charter, Women be exempt. (11. 33-34)

The Lady Geraldine pleads with Surrey, "If I doe erre, you know my Sexe is weake" (1. 17). Jane Shore attempts to justify her infidelity by asserting the insecurity of a woman in a man's world: "For men want mercie, and poore women strength" (1. 158). In fact nearly all of Drayton's women and several of his men allude to questions of feminine subservience and to the double standard of contemporary sexual ethics.

From Drayton's point of view, the most important link between the Elizabethan complaint and the Heroicall Epistles lies in his own complaint poems, Peirs Gaveston and Matilda. Neither of these works quite rises to the level of Rosamond or Lucrece, but both reveal Drayton's awareness of the vogue in which he was writing. Gaveston (1593 or 1594) recalls Rosamond in its opening recollections of the speaker's "tender youth" at court (11. 109-162), and in its concluding lines which describe his neglected tomb. Other influences are in evidence, of course (Edward II and Venus and Adonis chief among them), but Gaveston's "weeping woes" and anguished apostrophes were clearly inspired by Rosamond. In Matilda (1594) Drayton seldom wanders from Daniel's path: King John and a messenger replace Daniel's Henry and the "seeming matron," the heroine's father is

${ }^{5}$ Anthony Chute, Beawtie Dishonoured (1593); Lodge, Complaint of Elstred (1593); Drayton, Peirs Gaveston (159394), Matilda (1594); Churchyard's revised Shore's Wife (1593); Lucrece (1594); "Hen. Willoby," Willobie His Avisa (1594); Richard Barnfield, Complaint of Chastitie and Cassandra (1595); John Trussell, First Rape of Faire Hellen (1595).

- Cf. Heroides, tr. G. Showerman (London, 1914), xrx. 9-17, and Rosamond, 1594 (augmented) ed., 1. 714. Examples of feminine psychologizing in other complaint poems are numerous. The subject is perhaps most extensively treated in Daniel's Letter from Octavia to Marcus Antonius (1599), a poem which derives from Drayton's epistles and the complaint vogue.

${ }^{7}$ Rosamond, 1l. 372-413, noted by Tillotson, Works, v, 102. 
represented, and she does not fall. ${ }^{8}$ One might transpose whole passages from Matilda's wooing scenes and homilies to those of Rosamond and scarcely notice a difference; yet Matilda, like Gaveston, must have been widely read, for Drayton continued revising and republishing it until his death. ${ }^{9}$ Both poems ought to be read in the light of the Epistles, if only for an understanding of the achievement of the latter, which deal with much the same material in a tighter, more dramatically effective style.

The popularity of the Heroicall Epistles and Elizabethan complaints during Drayton's time may be explained in part by an examination of contemporary opinion on their common ancestor, the Heroides. Here again both kinds of poetry show their affinity to Ovid's work in that they exemplify the same moral didacticism and rhetorical profusion which Elizabethans saw, or thought they saw, in the Heroides. Henry Peacham, writing in Drayton's later years, placed Ovid "second in imitation" after Virgil. "Among his Workes," Peacham says, "his Epistles are most worthy your reading, being his neatest peeces, every where embellished with excellent and wise Sentences; the numbers smoothly falling in, and borrowing their lustre and beauty from imitation of native and antique Simplicity."10 The "wise Sentences" of the Heroides were traditionally thought to contain great moral sense. One scholar quotes a representative medieval belief to the effect that Ovid's intention in writing the epistles was to promote chaste love." Hubertinus Crescentinas' widely used fifteenth-century commentary on the Heroides echoes this view. ${ }^{12}$ The more sober epistles were common fare in Tudor classrooms: Erasmus urged schoolmasters to use them for the edification of their pupils, and they are known to have been in the curriculum at Eton in 1528 , perhaps at Erasmus' recommendation. ${ }^{13}$

Moral wisdom alone, however, could not account for the popularity of the Heroides. It was the Horatian dulce as well as the utile that attracted Renaissance humanists like Guido Morillonius, who wrote in a 1516 commentary on Ovid, "If Horace gave his vote for one who could combine the profitable and the pleasant, none, methinks, can excel Ovid in this art. He has so mingled the serious with honey-sweet fiction and fiction with the serious, that 'tis hard telling whether he offers us more pleasure than profit or more profit than pleasure."14 Ovid's smooth, aphoristic style, the neatly turned, well-planned speeches of his heroines could not fail to charm Guido's rhetorical-minded counterparts in Eng- land. We find a hint of their relish for "copie" in George Turbervile's preface to the first English translation of the Heroides (1567). In this translation, he urges:

If it be so that thou mislike anything, impute the blame to the Cooke. For doubtlesse the Cates of themselves in their kinde, are passing curious, but for want of cunning in dressing the same, may appeare nothing delectable in the eye, nor toothsome to the taste. The feast was devisde long agone by Ovid at Rome, \& passing well liked in learned Italie: no lesse for diversity of dishes, then copie of confictes. ${ }^{15}$

F. S. Boas once spoke of the "far-reaching" influence of Turbervile's Heroides, in that they made the characters of Greek legend widely accessible to those unable to read classical literature in the original. ${ }^{16}$ Yet more than likely, Elizabethan readers took as much delight in "copie of confictes" -in Ovid at his most rhetorical-as in the legends. Paradoxically, the countless variations on the same theme, which may often discourage modern readers of the Heroides, became a principal attraction of the work for readers in an age which assumed "copie" to be an essential quality of poetic style.

Throughout the Heroicall Epistles Drayton exercises care to balance the dulcedo of Horatian criticism with moral and historical utilitas. $\mathrm{He}$ declares as much in the prefatory statement, concerning the encyclopedic glosses or "Annotations" which follow each poem, that such notes are necessary "because the Worke might in truth be judged Braynish [i.e., governed by

${ }^{8}$ Drayton acknowledges Rosamond, Lucrece, Shore's Wife, and Lodge's Complaint of Elstred as forerunners of his "tragicall Historie" in Matilda, 11. 29-49 (1594 ed.).

- Five distinct states of the text of Gaveston are noted by J. W. Hebel, "The Surreptitious Edition of Michael Drayton's Peirs Gaveston," Library, Iv (1923), 151-155.

${ }^{10}$ The Compleat Gentleman (1622), ed. G. S. Gordon (Oxford, 1906), pp. 87-88.

"Fausto Ghisalberti, "Medieval Biographies of Ovid," $J W C I, \mathrm{xx}$ (1946), 11: "Intentio est castum amorem commendare, illicitum refrenare, et incestum condemnare."

${ }^{12} \mathrm{Cf}$. Heroides. Cum interpretibus Hubertino Crescent. \& Iano Parrhasio (Brescia, 1542), f. A1": "Materia vero est ethica: id est moralis quia describit varios virorum mulierumque mores." Needless to say, the Metamorphoses was also widely moralized in the Middle Ages.

${ }_{13}$ T. W. Baldwin, William Shakespere's Small Latine \&० Lesse Greeke (Urbana, Ill., 1944), II, 419. Cf. Erasmus, Opus de conscribendis epistolis (Cologne, 1569), p. 23: "Quanquam heroicarum sunt castiores: neque quidque vetat et hoc genus caste verecundeque tractari."

${ }^{14}$ Tr. in E. K. Rand, Ovid and His Influence (New York, 1925), pp. 155-156.

${ }_{15}$ The Heroycall Epistles of the Learned Poet Publius Ovidius Naso, ed. F. S. Boas (London, 1928), p. ix.

${ }^{16}$ Ovid and the Elizabethans, English Association Lecture (London, 1947), p. 10. 
passions], if nothing but amorous Humor were handled therein." 17 It was perhaps with this idea in mind that he felt it necessary to qualify his admission, in the same preface, that he was "partly" an imitator of Ovid; a comparison of his work with the Heroides will bear him out.

Like Ovid, Drayton had as the raw material for his work a number of legends and historical incidents already familiar to his readers. Like Ovid, he had not only to choose the proper moment in his lovers' careers for a dramatic exchange of letters, but to avoid monotony he had also to vary their situations. A mere acquaintance with the arguments of Drayton's epistles will show that they are more varied than Ovid's letters in that they are not restricted to stories of unrequited love. His lovers' sympathies run from the tragic (Duke Humphrey and Elinor Cobham) to the magnificent (Queen Katherine and Owen Tudor) to the sensual (King Edward and Jane Shore). There are faithful husbands and faithless wives, noble dames and obdurate lechers. As regards verbal similarities-and this point is important for an accurate understanding of Drayton's concept of imitatio-relatively few passages show deliberate recourse to Ovid. ${ }^{18}$ The detailed similarities between the two works reside chiefly in three or four of the lovers' situations. Queen Mary and Charles Brandon, like Hero and Leander, are separated by a Hellespont, the Channel; in fact Mary alludes pointedly to the Hero-Leander legend in the Ovidian rather than the Marlovian version. ${ }^{19}$ Edward IV and Jane Shore evoke more than once Ovid's Paris and Helen. Like Paris, Edward sees his future paramour as a diamond in the rough; ${ }^{20}$ he is as jealous of Jane's husband as Paris of Menelaus..1 Jane, in her reply, shows at first the same moral indignation as Helen, but like Helen she undergoes a change of heart as she writes. Perhaps Drayton's most conspicuously Ovidian heroine is Surrey's Lady Geraldine, who in her final couplet compares herself with Penelope:

Then, as Ulysses Wife, write I to thee, Make no reply, but come thy selfe to mee.

The fact that Drayton's Surrey is a wanderer, that he has neglected his domestic duties, ${ }^{22}$ and that Geraldine (like Penelope) exalts rustic simplicity over court life also contribute to the analogy.

More can be learned about the design of Englands Heroicall Epistles from the differences between Ovid and Drayton than from the similarities. Within their epistles, Ovid and Drayton alike must coordinate the objective context of legend and history with the speaker's presumed state of mind. The difference is primarily a matter of viewpoint: Ovid emphasizes the internal passions and feelings of his subjects (in this respect Ovid's poems have more in common with Browning's monologues than do Drayton's); in Drayton the speaker is governed as much by historical fact as subjective motive. To use Tillyard's distinction, the language of ceremony, as opposed to the language of passion, is most in evidence. ${ }^{23}$ This fundamental difference in the poets' attitudes (along with a certain academic bias) may explain the difference of opinion on the relative merits of characterization in Ovid and Drayton. F. A. Wright finds Drayton's attempts "gallant but not very successful";24 Hallett Smith, on the other hand, suggests that the character portrayal in Drayton's epistles compares favorably with that in the Heroides. ${ }^{25}$ Their evaluations notwithstanding, both would almost certainly agree that the characters in the Heroicall Epistles are more externalized than Ovid's. None of Drayton's lovers quite approaches Ovid's Paris and Helen in psychological depth-in revealing the state of mind common to certain kinds of lovers. One feels, however, that Paris and Helen are detached from the real world of policy and political maneuvering; that for them-as for all Ovidian lovers-nocturna bella are the only kind worth waging. The epistles of Paris and Helen, Drayton might have said, abound in "nothing but amorous Humor"; indeed Helen, Dido, and all their forsaken sisters can only have been "braynish" by Drayton's standards.

${ }^{17}$ Works, II, 130.

${ }^{18}$ Heinz Ludwig, Der Einfluss römischer Dichter auf das Werk Michael Draytons (diss. Köln, 1961), pp. 21-149, finds many verbal parallels, but a good number of these are rather tenuous: e.g., Katherine's "Love my sweet Tudor, that becomes thee best" (1. 156), and Helen's "Apta magis Veneri, quam sunt tua corpora Marti" (1. 255).

${ }^{19}$ See Mrs. Tillotson's note on ll. 15-17, Works, v, 128.

${ }^{20}$ Cf. Edward, 11. 33-50, and Ovid's Paris, 1l. 189-212.

${ }^{21}$ See Her. Xvi.213-234, where Paris' jealousy is most expressive. In Drayton's Epistle of Queen Mary, King Louis may be seen as a Menelaus figure (note especially her boasts of deception, $11.133 \mathrm{ff}$.):

${ }^{22}$ Namely, completing his family mansion:

Why art thou slack, whilst no man puts his hand

To raise the mount where Surrey's Towers must stand?

(Geraldine, 11. 151-152)

${ }^{23}$ Shakespeare's History Plays (London, repr. 1959), p. 247.

${ }^{24}$ The Lover's Handbook (London, 1928), p. 61. In agreement is L. Purser's introd. to Heroides, ed. A. Palmer (Oxford, 1898), p. xxviii.

${ }^{25}$ Elizabethan Poetry, p. 129. In agreement with Smith is Maurice Evans, English Poetry in the Sixteenth Century (London, 1955), p. 127. 
For Drayton, in his efforts to obtain a judicious balance between the utile and the dulce, the alternative to braynishness is learning-historical learning in particular. But for artistic purposes the chief value of the historical element in the Heroicall Epistles is that it imposes continuity, if not unity, on the whole work.

In the Heroides one discerns no overall plan or design, not even a chronological one. In Drayton's work the case is otherwise: his letters not only fall into chronological sequence but suggest a balanced structure in the whole collection as well. The twelve pairs of letters comprise three groups of four each. The first group describes attempts at seduction by a royal figure (Henry II, John; Edward the Black Prince, and Edward IV); the second concerns liaisons between a queen and a nobleman (Isabel and Mortimer, Katherine and Owen Tudor, Margaret and William de la Poole, Mary and Charles Brandon); the third group embodies consolations exchanged between faithful lovers (Richard II and Isabel, Duke Humphrey and Elinor, Surrey and Geraldine, Jane Gray and Dudley). The arrangement of these three groups within the work maintains at once a sense of unity and variety. The earliest epistles introduce the self-centered Plantagenet monarchs, groaning in most unkingly fashion:

Yet let me be with Povertie opprest,

Of Earthly Blessings rob'd, and dis-possest;

Let me be scorn'd, rejected, and revil'd,

And from my Kingdome let me live exil'd,

Let the Worlds Curse upon me still remaine,

And let the last bring on the first againe;

All Miseries that wretched Man may wound,

Leave for my Comfort onely Rosamond.

(Henry to Rosamond, 11. 63-70)

The last two pairs, in the consolation group, portray the love and loyalty of the selfless patriots (as Drayton sees them) Surrey and Jane Gray. The central four pairs recall a "darkest moment" in English history: Richard II's deposition, Duke Humphrey's betrayal, and the disintegrating influence of Margaret and Suffolk. This crisis is relieved only by the KatherineOwen Tudor epistles, which constitute a dramatic foreshadowing of England's future glory. Owen Tudor boldly addresses Henry's widow: "And why not Tudor, as Plantaginet?" (1. 90); then he traces his mythical lineage back to the Trojan Brutus. ${ }^{26}$ His role in the Heroicall Epistles is that of precursor--a harbinger of England's salvation and the voice of Providence.

Drayton's representation of Owen Tudor rather than Henry $\mathrm{V}$ as Katherine's lover lends support to the view that Drayton selected and arranged his epistles so that they would all tend to look forward to the culmination of English history in the greatness of his own age. Had he depicted Henry instead, he would have had to introduce what was for many Elizabethans a golden age in England's past. Instead, as seen through the eyes of Katherine and her lover, Henry's late reign is a great moment in history, but it is only a step toward the eventual reestablishing of Tudor's "Royall Consanguinitie.". Drayton was well acquainted with the glorious reign of Henry $\mathrm{V}$, which he would later proclaim in two of his finest poems, "The Ballad of Agincourt" and the long narrative Battaile of Agincourt. But this subject was not consistent with the plan of his Heroicall Epistles.

In Surrey's letter from Italy we seem to hear Drayton's own nationalistic voice calling for a thoroughly English culture which will outshine that of Italy:
I find no cause, nor judge I reason why, My Country should give place to Lumbardy; As goodly flow'rs on Thamesis doe grow, As beautifie the Bankes of wanton $P o$; As many Nymphs as haunt rich Armus strand, By silver Severne tripping hand in hand:

(11. 227-232)

Geraldine replies with an equally patriotic denunciation of Italianate Englishmen who, unlike her lover,

nothing more then England hold in scorne, So live as Strangers whereas they were borne:

(11. 129-130)

The patriotism of Surrey and Geraldine prepares the way for Jane Gray's consolation to Dudley, which furnishes a grand close to the whole epistolary sequence, and a reassurance for Elizabethans of the unerring protection of Divine Providence. It is toward these lines that all of the Heroicall Epistles have been tending:

Yet Heav'n forbid, that Maries Wombe should bring Englands faire Scepter to a forraine King;

But she to faire Elizabeth shall leave it, Which broken, hurt, and wounded shall receive it: And on her Temples having plac'd the Crowne, Root out the dregges Idolatry hath sowne;

And Sions glory shall againe restore,

Laid ruine, waste, and desolate before;

And from blacke Sinders, and rude heapes of Stones,

${ }^{26}$ Drayton's persistent references to the Tudor myth in Poly-Olbion seem to have perturbed young Selden, who in his "illustrations" to Song I wrote, "I should sooner have been of the Authors opinion (in more then Poeticall forme, standing for Brute) if in any Greeke or Latine Storie authentique, speaking of Aeneas and his planting in Latium, were mention made of any such like thing" (Works, Iv, 21). 
Shall gather up the Martyrs sacred Bones; And shall extirpe the Pow'r of Rome againe, And cast aside the heavie Yoke of Spaine.

(11. 171-182) 27

Jane Gray's trust in Providence is a prophecy of England's glory, but it is also a reconciliation, in Christian terms, of the conflict between man's actions and the power of Fate or Fortune. Throughout the Heroicall Epistles the strength of Drayton's characters may be gauged by the way in which they come to grips with this power. In the first pair King Henry complains, "Of all Reliefe hath Fortune quite bereft me?"' (1. 44). He has begun the descent on Fortune's wheel: his sons have rebelled against him, his wife and mistress despise him. His hope that Rosamond will restore him to the height of his fortunes is a pathetic attempt at rationalization:

For Thee, swift Time his speedie course doth stay, At thy Command, the Destinies obay; (11. 71-72)

Rosamond's answer is ominous if not chilling: "Age is alike, in Kings, and other Men" (1.46). In Richard II's epistle the mood of Drayton's work reaches its lowest ebb. Like Jane Gray and Dudley, he is imprisoned awaiting death; but his resignation savors of despondency:

Frost-starved-Winter doth inhabit here;

A place wherein Despaire may fitly dwell,

Sorrow best suiting with a cloudie Cell.

(11. 58-60)

In contrast, Owen Tudor is the instrument, not the victim of Fortune. "It was not Henries Conquests, nor his Court," that brought him to England, he writes,

Nor came I hither by some poore event,

But by th'eternall Destinies consent;

$\mathrm{He}$ assures $\mathrm{K}$ atherine to have no fears about the outcome of their marriage, "When it so long hath beene fore-told by Fate" (1. 48).

Duke Humphrey and William de la Poole also embody contrasting views of Fortune. The Duke's voice suggests that of the goddess Fortuna's own prophet:

Cast not thine Eye on such as mounted be,

But looke on those cast downe as low as we;

For some of them which proudly pearch so hie,

Ere long shall come as low as thou or I.

(ll. 141-144)

His enemy William de la Poole sees himself as the architect of his own fate. Man, he tells Queen Margaret, contains "a little World" within himself, "His Soule the Monarch, ever ruling there." Whatever his temporary condition may be,

$\mathrm{He}$ is a King, that in himselfe doth raigne; And never feareth Fortunes hot'st Alarmes, That bears against her Patience for his Armes.

(11. 28-30)

Beside Tudor, who recognized the workings of Destiny, William is a skeptic. His Renaissance view of man's ability to master his situation through "Patience" or "Suff'rance" discounts the effects of Fortune:

What should we sit to mourne and grieve all day,

For that which Time doth eas'ly take away?

What Fortune hurts, let Suff'rance only heale,

(11. 149-151)

Lady Jane Gray, on the other hand, trusts in the will of God rather than man. Only temporal, transitory things are subject to Fortune; the good man remains incorruptible:

For we in vaine relie on humane Lawes,

When Heaven stands forth to plead the righteous cause,

Thus rule the Skies in their continuall course, That yeelds to Fate, that doth not yeeld to force.

Mans wit doth build for Time but to devoure,

But Vertue's free from Time and Fortunes pow'r.

(11. 111-116)

In rejecting momentary fear for trust in the Divine will, Jane's husband Guilford Dudley repeats her auspicious theme:

And when we shall so happily be gone,

Leave it to heaven to give the rightfull Throne.

(1i. 117-118)

Drayton opposes the Mirror for Magistrates view that man is a toy of irrational Fortune; nevertheless, he sees the completely self-willed man as the image of Satan, the Machiavel, the usurper of Order. Man's hope must rest on a firm belief in Providence.

Drayton's work is not unique in this concern with Fortune and Providence, of course; it is endemic in Elizabethan literature. Willard Farnham has demonstrated that while later Elizabethan drama could "focus upon human character as progressive shaper of unhappy destiny," it "had not forgotten the medieval and Senecan Fortune" which obsessed poets of the Mirror and earlier tragedies. ${ }^{28}$ Irving Ribner has

${ }^{27}$ Drayton's note on this passage: "A Prophesie of Queene Maries Barrennesse, and of the happie and glorious Raigne of Queene Elizabeth; her restoring of Religion, the abolishing of Romish Servitude, and casting aside the Yoke of Spaine" (Works, II, 301).

${ }^{28}$ Medieval Heritage of Elizabethdn Tragedy; p. 419. 
noted that Elizabethan biographical playsamong which he includes Drayton's collaborative work Sir John Oldcastle - tend "to conceive of the world as governed by a providential scheme in which the lives of their heroes conform to the will of God."'29 Like much Elizabethan drama, as well as non-dramatic historical literature, the Heroicall Epistles view the past in the traditional, Augustinian concept of history as an extension of the will of God; the new, secular idea of history-represented on the Continent by Machiavelli and Guicciardini-is wholly alien to Drayton. ${ }^{30}$

It would be inaccurate to suggest that Drayton's adaptation of the Ovidian epistle was wholly an innovation. Chaucer had relied on the Heroides for much of The Legend of Good Women; his unfinished Anelida and Arcite may also owe something to Ovid's work, at least in the style and tone of "The Complaynt of Anelida the quene upon fals Arcite." The pseudo-Chaucerian "Letter of Dido to Eneas" (1526) is a free paraphrase of Ovid's seventh epistle. In Sapho and Phaon (acted 1584) Lyly dramatized a story made famous in Heroides xv. Elizabethans were familiar with Boccaccio's use of the Heroides through Bartholomew Yong's translation of Fiammetta in 1587. ${ }^{31}$ Donne's "Sapho to Philaenis" may have been composed independently of Drayton's work; certainly there is nothing in it to suggest a source in the Heroicall Epistles. Thus Drayton was not the first to see the possibilities of the Ovidian epistle; rather, he was original in imposing the unity of a historical theme on a collection of epistles which, at least with respect to character and situation, were even more diverse than the Heroides.

A close friend of Drayton, Sir William Alexander, greeted the Heroicall Epistles with a flattering but misleading hyperbole:

These Love-sicke Princes passionate estates, Who feeling reades, he cannot but allow, That Ovids Soule revives in Drayton now, Still learn'd in Love, still rich in rare Conceits. ${ }^{32}$

As Drayton's editors point out, after 1597 it became something of a commonplace to refer to him as "the English Ovid." "33 Yet in the Heroicall Epistles love and "rare Conceits" (one is reminded of Turbervile's "copie of confictes") are overshadowed by history as they never are in the Heroides. When Drayton prompted the classical form to respond to his own intellectual temper, the result was a wholly new, thoroughly English heroic epistle, Ovidian in concept but not in design. Ovid's soul "revived" only partly in Drayton, for as an artist he remained very much his own master and a representative of his age.

\section{UNIVERSITY OF KANSAS} Lawrence

${ }^{29}$ The English Historical Play in the Age of Shakespeare, rev. ed. (London, 1965), p. 223.

${ }^{30}$ On the two ideas of history see Leonard F. Dean, Tudor Theories of History Writing (Ann Arbor, Mich., 1947).

${ }^{31}$ In Capitolo IX (Book VII in Yong's version) Fiammetta recounts the misfortunes of Ovid's heroines.

${ }^{32}$ Works, II, 131, "To M. Michael Drayton." First printed in the 1600 ed.

${ }^{33}$ Works, v, 97. 